\title{
Napromienianie szpiku całego ciała — prezentacja metody
}

\author{
Grzegorz Głowacki ${ }^{1}$, Leszek Miszczyk¹, Krzysztof Ślosarek², Bożena Jochymek \\ Grzegorz Woźniak ${ }^{1}$, Łukasz Matulewicz ${ }^{2}$, Michał Radwan², Paulina Leszczyńska², \\ Łukasz Dolla², Jacek Najda ${ }^{3}$, Tomasz Krużel ${ }^{3}$, Tomasz Czerw ${ }^{3}$, \\ Maria Saduś-Wojciechowska ${ }^{3}$, Sebastian Giebel ${ }^{3}$
}

Transplantacja hematopoetycznych komórek macierzystych jest wykorzystywana w leczeniu niektórych nowotworów pochodzenia szpikowego lub limfatycznego. Transplantację poprzedza kondycjonowanie, oparte o chemioterapię samodzielną bądź w połączeniu z napromienianiem całego ciała (TBI). Z uwagi na dowiedzioną skuteczność TBI zastosowanie tej metody kondycjonowania ma szczególne uzasadnienie. Z uwagi na współistniejącą wczesną i późną toksyczność radioterapii w oparciu o techniki wielkopolowe poszukuje się nowych metod napromieniania.

W ramach badania II fazy (ClinicalTrials.gov NCT01665014) od 2012 roku w naszym ośrodku zastosowano zmodyfikowaną formę napromieniania chorych na szpiczaka plazmocytowego w postaci TMI (napromienianie szpiku całego ciała). Metoda wydaje się mieć uzasadnienie szczególnie w tych nowotworach, które lokalizują się głównie lub wyłącznie w szpiku kostnym, np. ostre białaczki lub szpiczak plazmocytowy.

W celu redukcji napromienianej objętości zdrowych tkanek oraz zmniejszenia toksyczności radioterapii wprowadzono metodę ograniczoną jedynie do napromieniania kości w oparciu o trójwymiarowy system planowania.

Do tej pory nie wypracowano metodologii TMI. Liczba publikacji dotyczących opisanego sposobu leczenia na świecie jest bardzo ograniczona.

Celem obecnej pracy jest przedstawienie metodologii TMI stosowanej w ramach naszego protokołu.

\section{Method of total marrow irradiation (TMI)}

Allogenic and autologous hematopoietic stem cell transplantation (HSCT) is widely used for the treatment of many myeloid and lymphoid malignancies. Conditioning precedes bone marrow transplantation. Chemotherapy alone or with radiotherapy (TBI — total bone marrow irradiation) are used to conditioning. The proven efficacy of TBI means that the use of this conditioning is essential even though it is limited by adverse effects: both acute and late toxicity. New methods of irradiation are desirable.

In our Institution we have performed a phase II study (ClinicalTrials.gov NCT01665014) from 2012 for patients with multiple plasmocytoma. The TMI we use is a modified form of TBI. It seems to be especially appropriate for the treatment of neoplasms located mainly or only in bone marrow (multiple myeloma, acute leukemias).

Limitation of irradiated volumes only to bones probably will reduce a toxicity of treatment.

Currently there are no internationally agreed methodological guidelines for TMI. Also there are only few publications on TMI.

The aim of this paper is to introduce the methodology of TMI used in our department.

NOWOTWORY Journal of Oncology 2014; 64, 4: 314-320

Słowa kluczowe: szpiczak mnogi, napromienianie szpiku całego ciała, TMI, tomoterapia, VMAT

Key words: multiple myeloma, total marrow irradiation, TMI, tomotherapy, VMAT

\footnotetext{
${ }^{1}$ Zakład Radioterapii

${ }^{2}$ Zakład Planowania Radioterapii i Brachyterapii

${ }^{3}$ Klinika Transplantologii i Onkohematologii

Centrum Onkologii — Instytut im. Marii Skłodowskiej-Curie, Oddział w Gliwicach
} 


\section{Wstęp}

W leczeniu wielu nowotworów złośliwych pochodzenia szpikowego bądź limfatycznego ma zastosowanie auto- lub allogeniczna transplantacja komórek macierzystych (HSCT - hematopoetic stem cell transplantation). W celu eliminacji komórek nowotworowych oraz zapobieżenia reakcji przeszczepu przeciwko gospodarzowi przed transplantacją stosuje się kondycjonowanie w postaci samodzielnej chemioterapii bądź w skojarzeniu z napromienianiem całego ciała (TBI - Total Body Irradiation).

Zastosowanie TBI jako części takiego leczenia w porównaniu z samodzielną chemioterapią ma szczególne uzasadnienie. W przeciwieństwie do chemioterapii umożliwia dostarczenie homogennej dawki do całego ciała chorego niezależnie od jego ukrwienia, nie wpływa na występowanie krzyżowej oporności z chemioterapeutykiem, umożliwia podwyższenie lub zmniejszenie dawki promieniowania w obszarach zainteresowania (stosowanie osłon). Dodatkowo umożliwia zniszczenie rezydualnych komórek nowotworowych w obszarach takich jak OUN czy jądra, gdzie stężenie chemioterapeutyków jest znacznie niższe niż w pozostałych tkankach.

Napromienianie całego ciała wciąż jeszcze nie jest wystandaryzowaną metodą leczenia i stosowane jest w bardzo wielu modyfikacjach [1]. Pomimo dowiedzionej skuteczności TBI w przygotowaniu do HSCT, metoda ta obarczona jest jednak ryzykiem występowania wczesnej i późnej toksyczności [2-6].

Z uwagi na powyższe istnieje tendencja do zastępowania TBI samodzielną chemioterapią.

Szybki rozwój technologiczny w radioterapii pozwolił obecnie na zastosowanie alternatywnej metody napromieniania chorych w postaci TMI (Total Marrow Irradiation), która to przy zachowaniu potencjału mieloablacyjnego TBI może pozwolić na ograniczenie toksyczności. Metoda ta stosowana jest w nielicznych ośrodkach na świecie, a liczba publikacji na ten temat jest ograniczona $[7,8]$.

Wydaje się, że zastosowanie TMI może mieć uzasadnienie szczególnie w tych nowotworach, które lokalizują się głównie lub wyłącznie w szpiku kostnym, np. ostre białaczki lub szpiczak plazmocytowy. Do tej pory nie wypracowano metodologii TMI.

W CO-I w Gliwicach od 2012 roku ma zastosowanie TMI w przygotowaniu do autoHSCT u chorych na szpiczaka plazmocytowego w ramach badania II fazy w sekwencji z dużymi dawkami melfalanu u 50 chorych (ClinicalTrials. gov NCT01665014).

Celem obecnej pracy jest przedstawienie metodologii TMI stosowanej w ramach tego protokołu.

\section{Opis metody}

W 2012 roku w Gliwickim Oddziale Centrum Onkologii — Instytucie im. Marii Skłodowskiej-Curie wdrożono, w ramach badania klinicznego prowadzonego przez Klinikę Transplantacji Szpiku i Onkohematologii, protokół napromieniania szpiku całego ciała u chorych na szpiczaka mnogiego.

Przed napromienianiem u chorych przeprowadzono mobilizację komórek macierzystych CD 34+ z zastosowaniem AraC i G-CSF $[9,10]$.

Przygotowanie chorego do napromieniania polegało na wykonaniu unieruchomienia w pozycji leżącej na plecach z zastosowaniem masek termoplastycznych w obszarze głowy, klatki piersiowej, tułowia oraz kończyn dolnych. W celu poprawy stabilności unieruchomienia stosowano dodatkowo klocki pod głowę, kolana oraz dodatkowe unieruchomienie stóp (ryc. 1). W kolejnym etapie wykonywano tomografię komputerową do planowania leczenia. W przypadku konieczności zastosowania dodatkowego boostu stosowano fuzję z badaniem PET lub NMR.

U każdego chorego wykonywano dwa plany leczenia: pierwszy — zzastosowaniem aparatu do tomoterapii (ryc. 2) oraz drugi - w oparciu o przyśpieszacz liniowy z zastosowaniem VMAT (Volumetric Modulated Arc Therapy) (ryc. 3).

Obszarem zainteresowania były (PTV — planning target volume) kości z wyłączeniem kości dłoni, żuchwy, szczęki i sitowia (ochrona gałek ocznych i soczewek) z marginesem 5 mm dla kości kończyn.

Narządy krytyczne (OAR — organs at risk) stanowiły: mózgowie, soczewki, jama ustna, płuca, serce, wątroba, nerki, jelita i pęcherz moczowy. Rekomendowane dawki w powyższych organach przedstawiono w tabeli I. Dodatkowo przyjęto maksymalną dawkę w organach krytycznych, nieprzekraczającą 130\% dawki zadanej. Dopuszczano przekroczenie dawki całkowitej o 20\% w nie więcej niż 2\% objętości oraz o 10\% — w nie więcej aniżeli 10\% napromienianej objętości. Przyjęto jako wystarczające pokrycie $85 \%$ objętości PTV izodozą 99\% dawki zadanej (planowanej, tj. 12 Gy). Dopuszczalna dawka maksymalna w całej objętości ciała pacjenta nie przekraczała 130\% dawki zadanej, tj. 15,6 Gy.

W obu technikach napromieniania stosowano dawkę frakcyjną 4 Gy do dawki całkowitej 12 Gy, podanej w ciągu trzech kolejnych dni. Minimalna wymagana przerwa pomiędzy frakcjami wynosiła 12 godzin. $U$ chorych z rozpoznanymi aktywnymi metabolicznie ogniskami gromadzenia radioznacznika w badaniu PET/CT podwyższano dawkę w obszarze wyżej wymienionych ognisk sześcioma dodatkowymi frakcjami po $4 \mathrm{~Gy}$ do całkowitej dawki $36 \mathrm{~Gy}$. W tym celu wykonywano fuzję badań PET/CT i badania CT do planowania leczenia. Podwyższoną dawkę stosowano u chorych, u których liczba aktywnych ognisk nie przekraczała pięciu. Boost realizowano w oparciu o technikę radioterapii, która w danych warunkach była najbardziej odpowiednia. Dopuszczano planowanie przy użyciu CRT — radioterapii konformalnej, IMRT — radioterapii z intensywną modulacją mocy dawki, Rapid Arc — dynamicznej radioterapii obroto- 


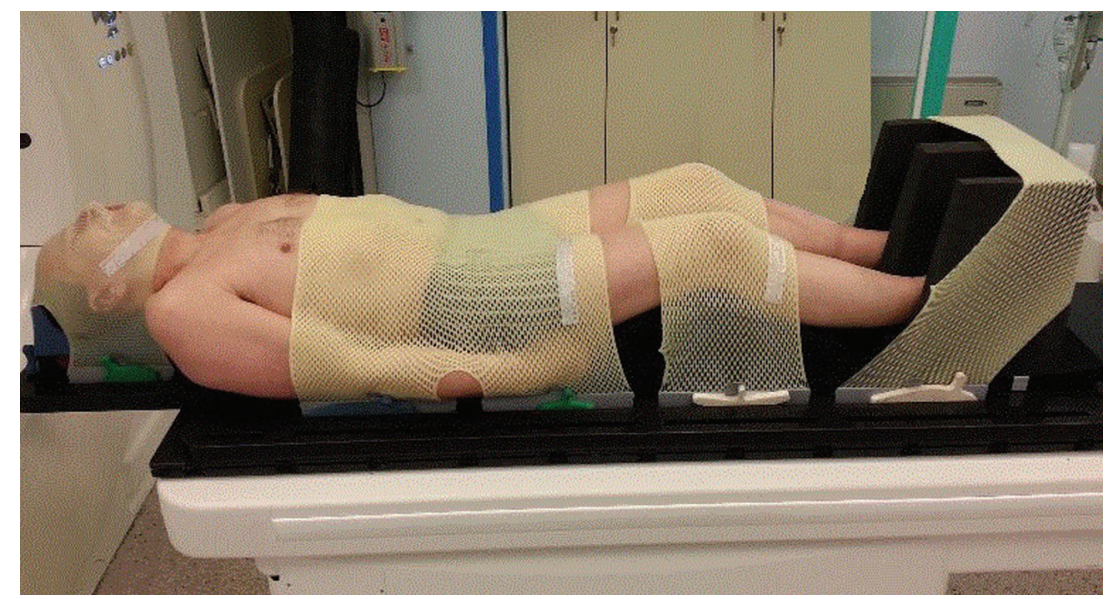

Rycina 1. Unieruchomienie chorego
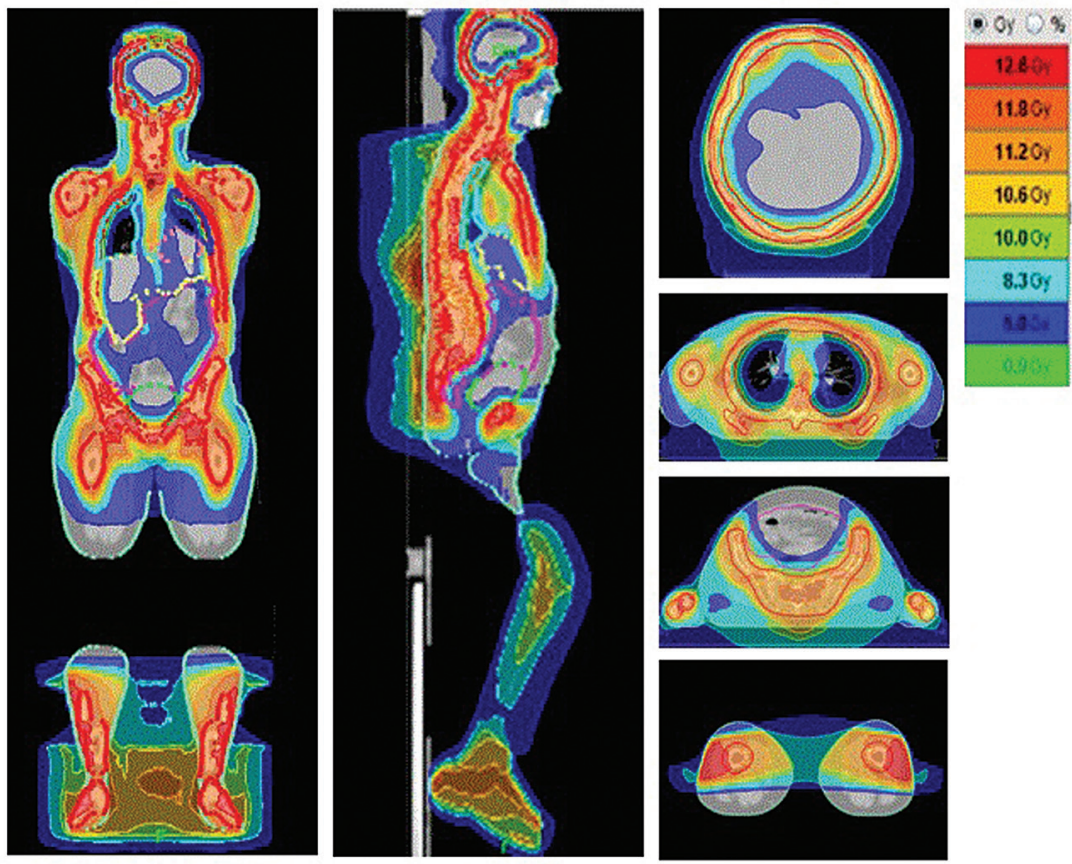

Rycina 2. Rozkład dawki promieniowania z zastosowaniem planowania w tomoterapii
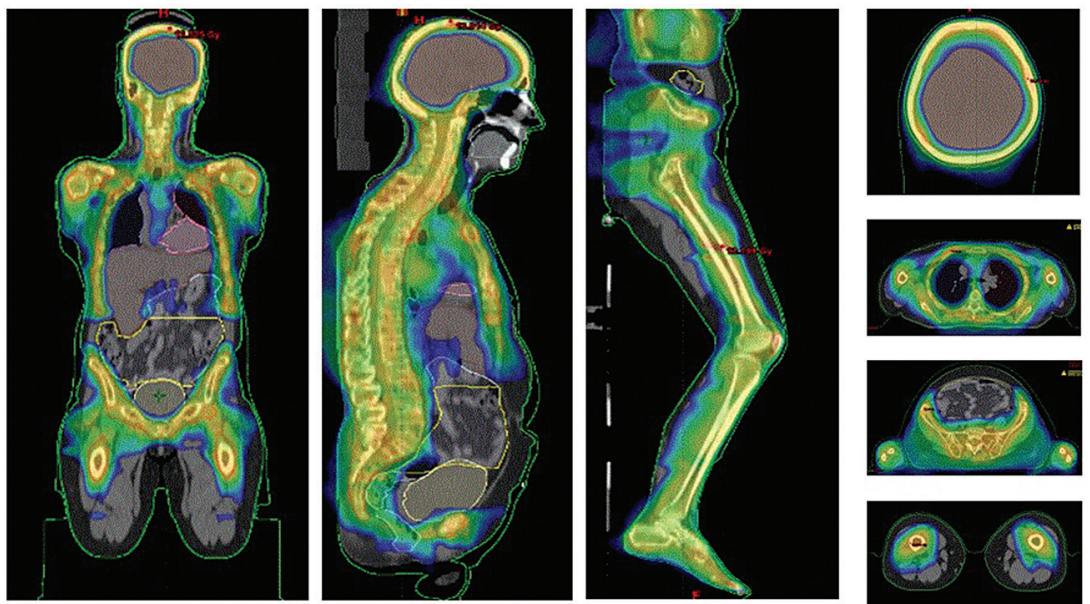

Rycina 3. Rozkład dawki promieniowania z zastosowaniem planowania VMAT 
Tabela I. Rekomendowane dawki średnie i mediany w narządach krytycznych

\begin{tabular}{lcc}
\hline & Dawka średnia (Gy) & Mediana dawki (Gy) \\
\hline Mózgowie & 7,6 & 7,5 \\
Soczewka & 3,0 & 3,0 \\
Jama ustna & 5,5 & 5,0 \\
Płuca & 8,0 & 8,0 \\
Serce & 8,0 & 7,3 \\
Wątroba & 7,5 & 7,0 \\
Nerki & 6,5 & 5,7 \\
Jelita & 7,7 & 7,0 \\
Pęcherz moczowy & 6,7 & 5,8 \\
\hline
\end{tabular}

wej czy tomoterapii. Dodatkową dawkę podawano w ciągu sześciu dni poprzedzających napromienianie szpiku.

W premedykacji u chorych stosowano ondansetron w dawce 8 mg dożylnie na jedną godzinę przed napromienianiem, w razie potrzeby hydroksyzynę lub leki z grupy benzodiazepin.

\section{Tomoterapia}

Ze względu na ograniczenie wynikające z maksymalnej długości napromienianego obszaru, w osi długiej do $160 \mathrm{~cm}$, napromienianą objętość podzielono na dwie części. Pierwsza obejmowała ciało pacjenta od czubka głowy do połowy długości kości udowych, druga to objętość od połowy długości kości udowych do stóp pacjenta. Łączenie objętości napromienianych w TMl odbywało się w połowie kości udowych.

Górną część objętości napromieniano z zastosowaniem techniki helikalnej (napromienianie przy pomocy obracającego się źródła promieniowania przy jednoczesnym przesuwie stołu wzdłuż osi długiej), dolną — z zastosowaniem dwóch naprzeciwległych pól bocznych przy jednoczesnym przesuwie stołu (Tomo Direct). Tomoterapię realizowano przy użyciu fotonów $6 \mathrm{MV}$.

Leczenie realizowano po wykonaniu procedur dozymetrycznych QA (Quality Assurance) u każdego chorego. W tym celu dokonywano pomiaru dawki za pomocą dwóch komór jonizacyjnych w uprzednio wyznaczonych punktach osobno dla planów wykonanych w technice helikalnej i technice direct. Dodatkowo dla techniki helikalnej przeprowadzano pomiar przy pomocy fantomu Octavius II z matrycą 2D-ARRAY, weryfikując rozkład dawki podawanej w rejonie głowy chorego.

Do weryfikacji ułożenia stosowano tomografię megawoltową (MVCT) w obszarze głowy i szyi, miednicy oraz kończyn dolnych przed każdą frakcją napromieniania. Po nałożeniu obrazów weryfikacyjnych z obrazami tomograficznymi z planowania leczenia dokonywano korekcji ułożenia we wszystkich płaszczyznach (ryc. 4).

\section{VMAT (Rapid Arc)}

Planowanie prowadzono w systemie Eclipse z zastosowaniem odwrotnego planowania (inverted planning). W procesie planowania leczenia wykorzystano algorytm AAA w wersji 10.0.28, który umożliwia jednoczesną optymalizację 10 łuków.

Objętość tarczową napromieniano z zastosowaniem 9 izocentrów (głowa, klatka piersiowa, lewa kończyna górna, prawa kończyna górna, jama brzuszna, miednica, uda, podudzia i stopy) po jednym lub po dwa łuki w każdym z izocentrów (ryc. 5, 6).

Do planowania wykonywano tomografię komputerową od czubka głowy do stóp. W pierwszym etapie przygotowano plan leczenia górnej części napromienianej objętości do wysokości połowy długości kości udowych.

Ze względu na ograniczoną możliwość przesuwu stołu w osi długiej na aparacie terapeutycznym konieczne jest obrócenia chorego o 180 stopni (stopami do głowicy).Z uwagi na powyższe pozostałą część objętości tarczowej planowano na obróconej tomografii. W ostatnim etapie dokonywano fuzji obu tomografii orazłączenia napromienianych objętości. Leczenie prowadzono techniką pól łączonych z zastosowaniem procedur IGRT (Image Guided Radiotherapy) w oparciu o system OBI (On-Board Imaging). Do weryfikacji położenia każdego z izocentrów stosowano system 2D-2D KV.
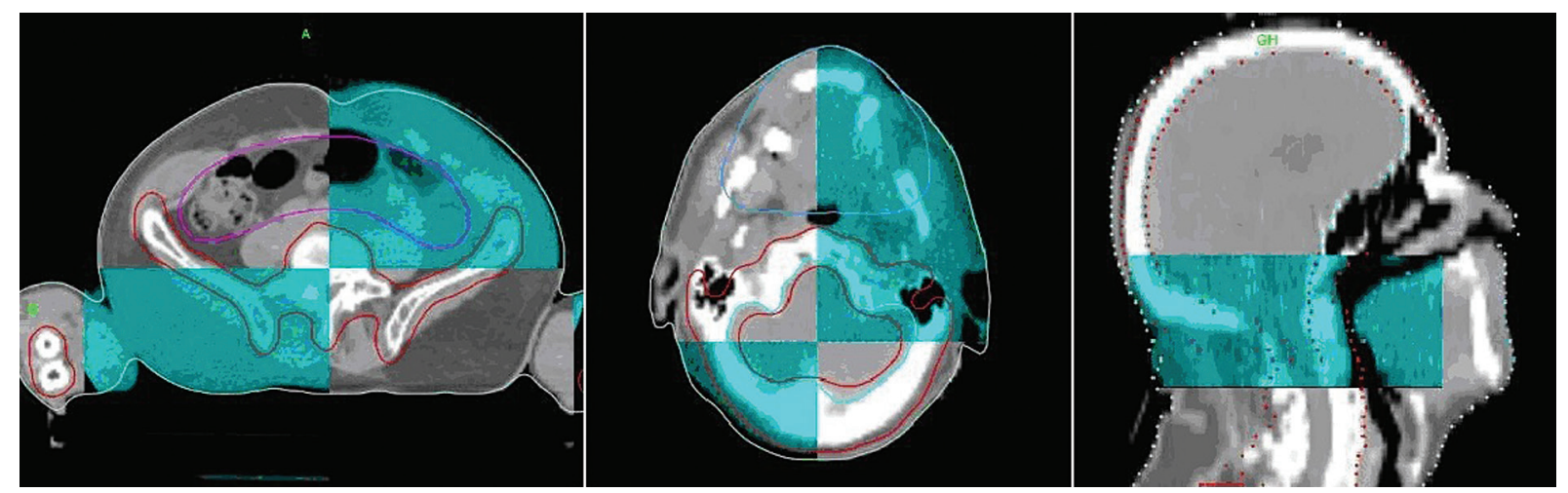

Rycina 4. Weryfikacja ułożenia. Nałożono obrazy CT z planowania leczenia i obrazy weryfikacyjne MVCT 

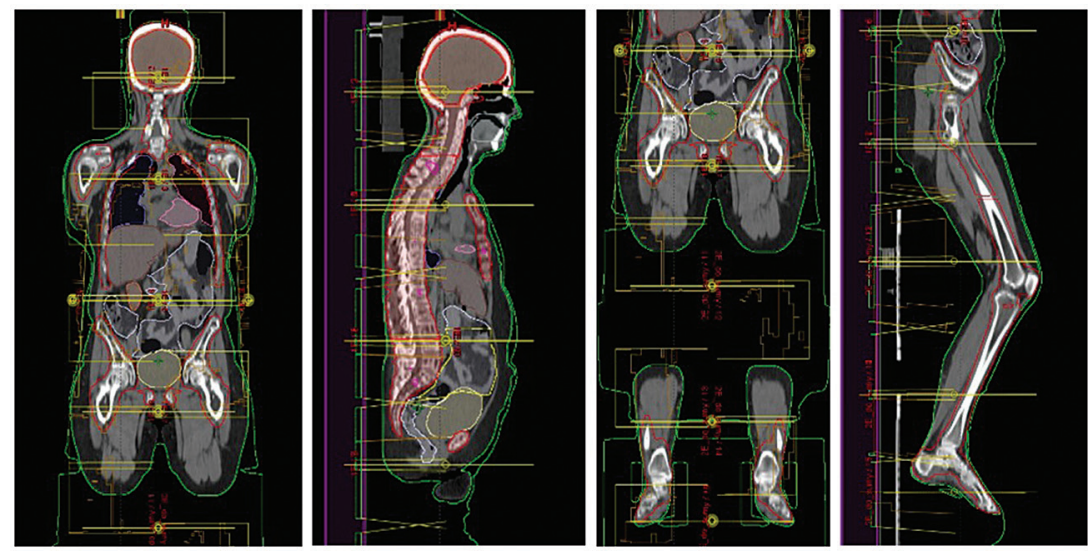

Rycina 5. Planowanie z zastosowaniem łączonych pól techniką Rapid Arc (zaznaczono położenie izocentrów w dwóch płaszczyznach)
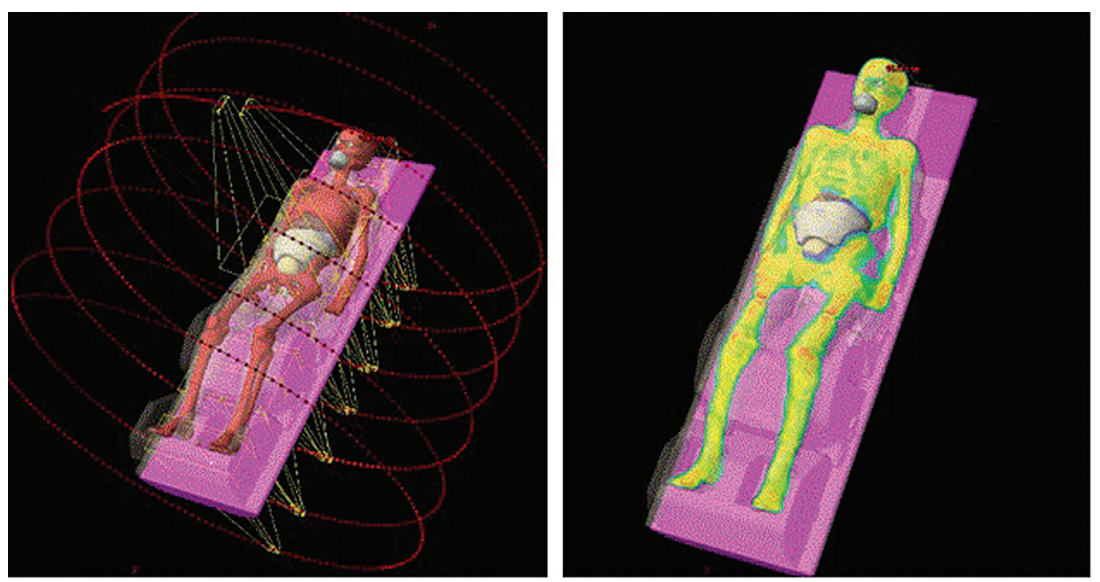

Rycina 6. Planowanie z zastosowaniem łączonych pól techniką Rapid Arc (widok trójwymiarowy)

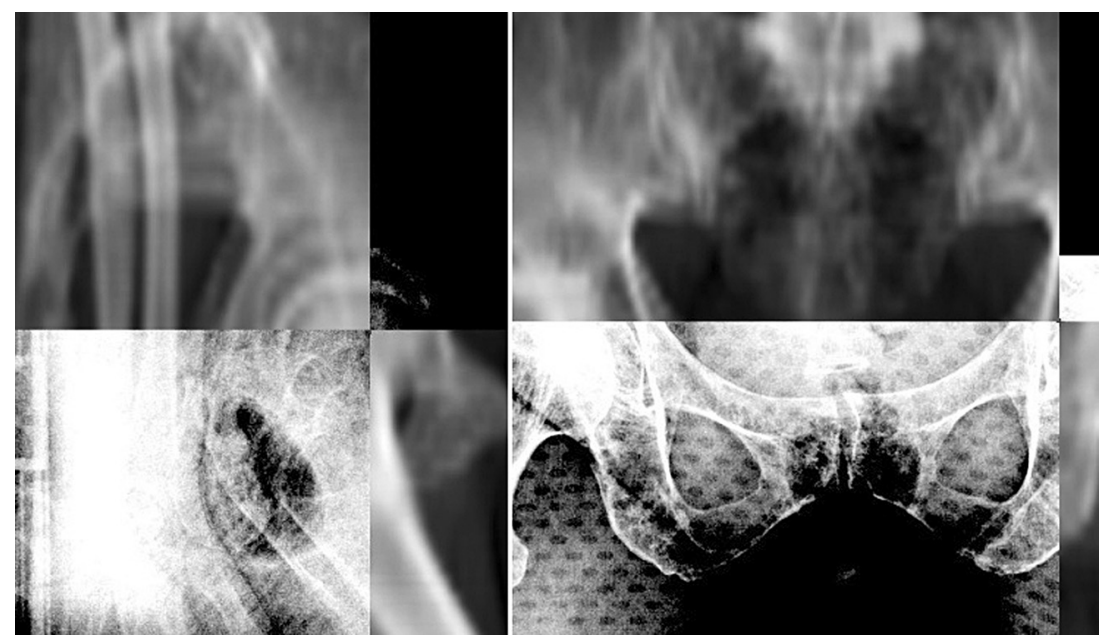

Rycina 7. Weryfikacja ułożenia z zastosowaniem 2D-2D KV (nałożone obrazy DRR z planowania leczenia i obrazy kV)

Wykonywano w każdym przypadku zdjęcia w dwóch prostopadłych do siebie płaszczyznach z zastosowaniem promieniowania kilowoltowego (ryc. 7). W celu zniwelowania możliwości nałożenia się pól napromieniania w objętości rdzenia kręgowego po ostatecznej weryfikacji położenia pierwszego izocentrum w obszarze głowy, w kolejnych nie 
dokonywano korekcji przesunięcia w osi długiej. Podobnie jak w przypadku tomoterapii, u każdego chorego przed rozpoczęciem leczenia dokonywano kontroli dozymetrycznej planów leczenia.

\section{Dyskusja}

Kondycjonowanie jest nieodzowną częścią leczenia przed wykonaniem transplantacji komórek macierzystych. Pod koniec lat 50. zastosowano po raz pierwszy w tym celu TBI [11]. Używano jednostki kobaltowej, stosując jednorazowo dawkę 10 Gy z dwóch pól naprzeciwległych [12,13]. Stopniowo aparaty kobaltowe zastępowano przyśpieszaczami liniowymi, a napromienianie prowadzono w kilku frakcjach.

W latach 80. i 90. prowadzono badania dotyczące toksyczności napromieniania całego ciała. W kilku retrospektywnych badaniach porównujących schematy zawierające lub niezawierające TBI w przygotowaniu do autoHSCT stwierdzono tylko nieznacznie większą częstość wystąpienia zapalenia płuc w grupach, gdzie stosowano napromienianie $[3,4,14]$. Wpływ dawki całkowitej wTBI na toksyczność płucną był także przedmiotem badań. Nie stwierdzono różnicy w częstości występowania toksyczności płucnej pomiędzy dawkami całkowitymi 12 i 14,4 Gy [4]. W innym badaniu Sobecksa i wsp. stwierdzono toksyczność płucną u 27\% chorych napromienianych do dawki całkowitej 15,3 Gy [5].

Napromienianie szpiku całego ciała zostało po raz pierwszy zastosowane w kontekście transplantacji tandemowych przez Zauchę i wsp. w Seattle w latach dziewięćdziesiątych ubiegłego wieku [7]. Zastosowano zmodyfikowaną wersję TBI techniką dwóch pól naprzeciwległych. W celu podania wyższej dawki całkowitej stosowano radioterapię hiperfrakcjonowaną dawką frakcyjną 1,5 Gy. Napromieniano dwa razy dziennie z zachowaniem sześciogodzinnej przerwy pomiędzy frakcjami. Dawka całkowita w kolejnych fazach badania wyniosła 12 Gy, 13,5 Gy oraz 15 Gy. Stosowano promieniowanie fotonowe o energii $6 \mathrm{MV}$ przy użyciu akceleratora liniowego. Podczas napromieniania używano indywidualnych osłon na płuca oraz wątrobę, a osłanianą ścianę klatki piersiowej dopromieniano za pomocą pól elektronowych. W grupie 57 pacjentów z nowotworami układu krwiotwórczego i chłonnego, w tym u 21 z MM, u których TMI stosowano jako przygotowanie do drugiej autoHSCT, stwierdzono dobrą tolerancję TMI w dawkach łącznych 12 Gy i 13,5 Gy. W przypadku dawki 15 Gy stwierdzono nadmierną wczesną toksyczność płucną 3 lub 4 stopnia u $24 \%$ chorych. W grupie 15 chorych (37\%) stwierdzono późny odczyn w postaci popromiennego zwłóknienia płuc, z czego u 13 - przewlekły kaszel lub duszność wysiłkową 1 i 2 stopnia. W grupie chorych napromienianych do całkowitej dawki 15 Gy toksyczność płucna była bardziej nasilona. Jeden chory zmarł wskutek powikłań płucnych, kolejny wymagał transplantacji płuc. Popromienna zaćma dotyczyła
$20 \%, 29 \%$ i $21 \%$ chorych napromienianych odpowiednio do dawek całkowitych $12 \mathrm{~Gy}, 13,5 \mathrm{~Gy}$ oraz $15 \mathrm{~Gy}$.

W 2005 r. Hui i wsp. przedstawili fizyczne aspekty i możliwość zastosowania tomoterapii w napromienianiu całego ciała lub szpiku całego ciała. Metoda ta umożliwiła zarówno skrócenie czasu leczenia, jak również zmniejszenie dawki w narządach krytycznych [15].

W badaniu Somla [8] i wsp. stosowano TMl z wykorzystaniem tomoterapii jako przygotowanie do drugiej autoHSCT u 22 chorych na MM. Dawka frakcyjna wynosiła 2 Gy, a dawkę łączną w kolejnych fazach badania eskalowano od 10 do $18 \mathrm{~Gy}$. Maksymalną dawkę tolerowaną ustalono na poziomie $16 \mathrm{~Gy}$. U chorych, u których stosowano dawkę $18 \mathrm{~Gy}$, wystąpiły powikłania, takie jak zastoinowa niewydolność serca, popromienne zapalenie płuc oraz zapalenie jelit.

W badaniu Wonga i wsp. porównano rozkłady dawek w narządach krytycznych pośród chorych planowanych z zastosowaniem standardowego napromieniania całego ciała do dawki całkowitej 12 Gy lub szpiku całego ciała za pomocą tomoterapii [16]. Uzyskano znacznie korzystniejsze rozkłady w narządach krytycznych po zastosowaniu tej drugiej metody. Uzyskano dwukrotne zmniejszenie median dawek promieniowania w płucach, wątrobie, nerkach i sercu. Trzykrotnie zmniejszono mediany dawek w mózgowiu i siedmiokrotnie w soczewkach. Pomimo zastosowania osłon płuc w technice TBI ponad $40 \%$ objętości tego narządu otrzymywało dawkę 10 Gy i wyższą, a całe płuca — dawkę 6 Gy i wyższą. Wykorzystując tomoterapię, dawka w płucach wynosiła jedynie 6 Gy w 20\% napromienianej objętości. W badaniu wykazano również lepszy rozkład dawki w narządach krytycznych, szczególnie w płucach w przypadku eskalacji dawki całkowitej w TMI do 20 Gy w porównaniu z klasycznym TBI, pomimo niższej dawki wynoszącej $12 \mathrm{~Gy}$.

W kolejnym badaniu Wong i wsp. potwierdzili opublikowane wcześniej obserwacje i wyniki analiz dozymetrycznych w odniesieniu do toksyczności [17]. Trzynastu chorych na szpiczaka mnogiego napromieniano z zastosowaniem tomoterapii na obszar szpiku całego ciała do dawek 10-16 Gy. U wszystkich chorych obserwowano toksyczność 1 lub 2 stopnia. Nie obserwowano toksyczności 4. stopnia, a toksyczność w stopniu 3 dotyczyła jedynie 2 chorych. Mediana obserwacji wynosiła 13 miesięcy. U 5 chorych utrzymywała się całkowita remisja, u jednego bardzo dobra częściowa remisja, u 4 częściowa remisja, u 2 chorych stabilizacja choroby. Obserwowano progresję po 9 miesiącach u jednego chorego, którego napromieniano do dawki całkowitej 10 Gy.

Możliwość zastosowania radioterapii z wykorzystaniem klasycznych akceleratorów liniowych z modulacją intensywności dawki i zastosowaniem techniki obrotowej (RapidArc) była również przedmiotem badań w kontekście TMI [18, 19]. Wykazano korzyść w postaci zaoszczędzenia zdrowych tkanek przy jednoczesnym dobrym pokryciu dawką obszarów tarczowych. 
Postęp technologiczny w radioterapii onkologicznej, jaki dokonuje się w ostatnich kilkunastu latach, pozwala na zastąpienie wielkopolowych technik dwuwymiarowych technikami 3D, umożliwiającymi optymalizację i indywidualizację leczenia chorych. Pozwala to na poznanie dokładnego rozkładu dawki zarówno w tkankach zdrowych, jak i w obszarze tarczowym. Bardzo ograniczona ilość publikacji wskazuje na akceptowalną tolerancję takiego leczenia. Obecnie brak jeszcze dużych badań randomizowanych, pozwalających na ocenę toksyczności i skuteczności takiego leczenia w porównaniu z dotychczas stosowanymi metodami. Wstępne obserwacje kliniczne dotyczące prowadzonego w Gliwicach badania sugerują bardzo dobry efekt mieloablacyjny leczenia przy akceptowalnej oraz niskiej toksyczności [20].

W prezentowanej przez nasz ośrodek metodzie TMI stosowano jako przygotowanie do pierwszej z dwóch transplantacji tandemowych. W planowaniu leczenia zastosowano dwie metody: w oparciu o tomoterapię, jak i dynamiczne techniki z zastosowaniem przyśpieszacza liniowego. Porównanie technicznych aspektów planowania obu technik będzie tematem kolejnych badań.

TMI w dłuższej perspektywie prawdopodobnie zastąpi TBI w napromienianiu chorych na szpiczaka mnogiego. Przyczyną tego jest fakt, iż w większości przypadków choroba ta dotyczy kości, w związku z powyższym napromienianie pozostałych zdrowych tkanek nie jest konieczne. Ma to szczególnie duże znaczenie dla ochrony tkanek zdrowych. Indywidualizacja leczenia pozwoli na zmniejszenie toksyczności oraz umożliwi eskalację dawki promieniowania.

\section{Konflikt interesu: nie zgłoszono}

\section{Dr n. med. Grzegorz Głowacki}

Centrum Onkologii — Instytut im. Marii Skłodowskiej-Curie Oddział w Gliwicach

ul. Wybrzeże Armii Krajowej 15, 44-101 Gliwice

e-mail:geno@poczta.onet.pl

Otrzymano: 19 maja $2014 \mathrm{r}$.

Przyjęto do druku: 16 czerwca 2014 r.

Lista stosowanych skrótów:

TBI — napromienianie całego ciała

TMI — napromienianie szpiku całego ciała

HSCT — transplantacja hematopoetycznych komórek macierzystych

VMAT - wolumetryczna modulowana terapia łukowa

IGRT — radioterapia kierowana obrazem

OAR - organ krytyczny

DRR — zrekonstruowany cyfrowo radiograf

IMRT — radioterapia z modulacją intensywności mocy dawki

\section{Piśmiennictwo}

1. Giebel S, Miszczyk L, Slosarek K i wsp. Extreme heterogeneity of myeloablative total body irradiation techniques in clinical practice: A survey of the Acute Leukemia Working Party of the European Group for Blood and Marrow Transplantation. Cancer 2014 May 7. doi: 10.1002/cncr.28768.

2. Leiper AD. Late effects of total body irradiation. Arch Dis Child 1995; 72 : 382-385.

3. Morgan T, Falk P, Kogut N i wsp. A comparison of single-dose and fractionated total-body irradiation on the development of pneumonitis following bone marrow transplantation. Int J Radiat Oncol Biol Phys 1996; 36: 61-66.

4. Hartsell W, Czyzewski E, Ghalie R i wsp. Pulmonary complications of bone marrow transplantation: a comparison of total body irradiation and cyclophosphamide to busulfan and cyclophosphamide. Int J Radiat Oncol Biol Phys 1995; 32: 69-73.

5. Sobecks R, Daugherty C, Hallahan D i wsp. A dose escalation study of total body irradiation followed by high dose etoposide and allogeneic blood stem cell transplantation for the treatment of advanced hematologic malignancies. Bone Marrow Transplant 2000; 25: 807-813.

6. Buchali A, Feyer P, Groll J i wsp. Immediate toxicity during fractionated total body irradiation as conditioning for bone marrow transplantation. Radiother Oncol 2000; 54: 157-162.

7. Zaucha R, Buckner D, Barnett T i wsp. Modified total body irradiation as a planned second high-dose therapy with stem cell infusion for patients with bone-based malignancies. Int J Radiat Oncol Biol Phys 2006; 64: 227-234.

8. Somlo G, Spielberger R, Frankel P i wsp. Total marrow irradiation: a new ablative regimen as part of tandem autologous stem cell transplantation for patients with multiple myeloma. Clin Cancer Res 2011; 17: 174-182.

9. Giebel S, Kruzel T, Czerw T i wsp. Intermediate-dose Ara-C plus G-CSF for stem cell mobilization in patients with lymphoid malignancies, including predicted poor mobilizers. Bone Marrow Transplant 2013; 48: 915-921.

10. Basak G, Jaksic O, Koristek Z i wsp. Haematopoietic stem cell mobilization with plerixafor and G-CSF in patients with multiple myeloma transplanted with autologous stem cells. Eur J Haematol 2011; 86: 488-495.

11. Thomas E, Lochte H, Cannon J i wsp. Supralethal whole body irradiation and isologous marrow transplantation in man. J Clin Invest 1959; 38: 1709-1716.

12. Thomas E, Buckner C, Banaji M i wsp. One hundred patients with acute leukemia treated by chemotherapy, total body irradiation, and allogeneic marrow transplantation. Blood 1977; 49: 511-533.

13. Thomas E, Buckner C, Clift R i wsp. Marrow transplantation for acute nonlymphoblastic leukemia in first remission. N Engl J Med 1979; 301: 597-599.

14. Wingard J, Sostrin M, Vriesendorp H i wsp. Interstitial pneumonitis following autologous bone marrow transplantation. Transplantation $1988 ; 46: 61-65$.

15. Hui S, Kapatoes J, Fowler J i wsp. Feasibility study of helical tomotherapy for total body or total marrow irradiation. Med Phys 2005; 32: 3214-3224.

16. Wong J, Liu A, Schultheiss T i wsp. Targeted total marrow irradiation using three-dimensional image-guided tomographic intensity-modulated radiation therapy: an alternative to standard total body irradiation. Biol Blood Marrow Transplant 2006; 12: 306-315.

17. Wong J, Rosenthal J, Liu A i wsp. Image-guided total-marrow irradiation using helical tomotherapy in patients with multiple myeloma and acute leukemia undergoing hematopoietic cell transplantation. Int J Radiat Oncol Biol Phys 2009; 73: 273-279.

18. Fogliata A, Cozzi L, Clivio A i wsp. Preclinical assessment of volumetric modulated arc therapy for total marrow irradiation. Int J Radiat Oncol Biol Phys 2011; 80: 628-636.

19. Aydogan B, Yeginer M, Kavak G i wsp. Total marrow irradiation with RapidArc volumetric arc therapy. Int J Radiat Oncol Biol Phys 2011; 81: 592-599.

20. Giebel S, Krużel T, Saduś-Wojciechowska M i wsp. Tandem autoHSCT with sequential use of total marrow irradiation and high-dose melphalan In multiple myeloma. Interim analysis of a phase II clinical trial $40^{\text {th }}$ Annual Meeting of the European Group for Blood and Marrow Transplantation, Milano Italy. Bone Marrow Transplant 2014; 49: S74. 